\title{
STUDY OF METOPIC SUTURE
}

\section{Sharada B Menasinkai ${ }^{1}$, Vidya H K ${ }^{* 2}$, M N Koti ${ }^{3}$.}

${ }^{1}$ Professor and HOD, Department Of Anatomy, AIMS BG Nagar, Bellur, Karnataka, India.

${ }^{* 2}$ Associate Professor, Department Of Anatomy, Shridevi Institution Of Medical Sciences And Research Hospital, Sira Road, Tumkur, Karnataka, India.

${ }^{3}$ Professor \& HOD, Department Of Anatomy SIMS \& RH Tumkur, Karnataka, India.

\section{ABSTRACT}

Background: Cranial sutures and their evolution is interesting in the field of cranial growing and shaping. It is a dentate suture extending from nasion to bregma. Metopic suture normally closes at $1-3 \mathrm{yrs}$, but is allowed up to 8 yrs. Incidence varies in different races from $1 \%-12 \%$.

Aim: The present study was done to know the incidence of Metopic suture in south Indian skulls.

Materials and Methods: 100 skulls from the Anatomy Dept museum at Shridevi Institute of Medical Sciences Tumkur were collected for the present study. The skulls with persistent metopic suture were thoroughly observed.

Results: Metopic suture was present in 38\%. Complete suture was seen in $3 \%$ and incomplete in $35 \%$.Among the 3 complete sutures one was linear and continue with sagittal suture measuring $12.3 \mathrm{~cm}$ and 2 were $\mathrm{H}$ shaped measuring $11.0 \mathrm{~cm}$ and $12.1 \mathrm{~cm}$. Incomplete sutures were classified depending on the shape $U, V, Y$ and linear. Linear suture was seen in 26 skulls, $U$ shape in 4 skulls, V shape 4 skulls, Y shape 1 skull.

Conclusion: The presence of metopic suture is important from a clinical point of view. It must be included in differential diagnosis of suspected skull fracture particularly frontal bone. It is not a pathological entity but most certainly should be noted as an incidental finding on an $X$ ray. The suture is best identified in $A-P$ view of skull.

KEY WORDS: Metopic Suture (M S), Frontal Bone, Ossification,

Address for Correspondence: Dr.Vidya H K, Associate Professor, Department Of Anatomy, Shridevi Institution Of Medical Sciences And Research Hospital, Sira Road, Tumkur-572106, Karnataka, India.Ph No.9611810464, E-Mail: vidyassmc@gmail.com

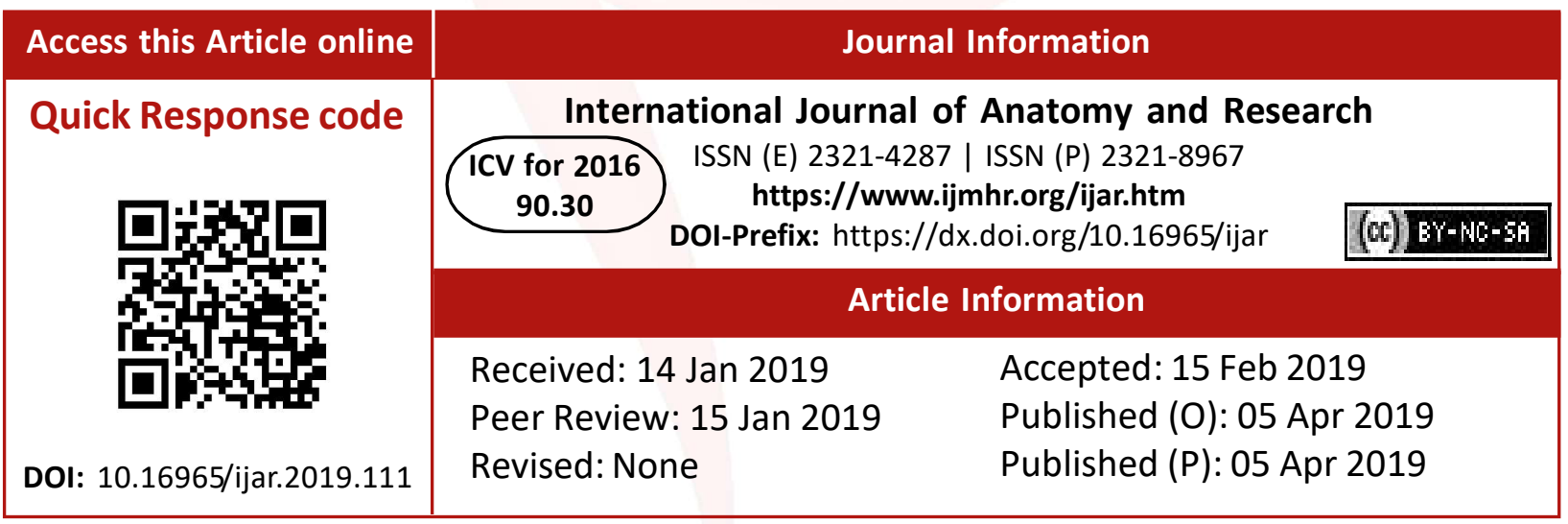

\section{INTRODUCTION}

The metopic or frontal suture is formed at the meeting of the two halves of frontal bone in the midline. Normally it starts to close in the second year of life and within a short duration, gets completely obliterated. At times there may be a partial or complete failure of obliteration. Metopism is referred as complete suture extending from nasion to bregma. When metopic suture is persistent it is a dentate suture about
$2 \mathrm{~cm}$ anterior to coronal suture it becomes simple and direct known as pars bregmatica. Usually the posterior end of the metopic suture does not meet the sagittal suture and may miss it by an interval as great as $15 \mathrm{~mm}$. Similarly the anterior end fails to meet intranasal suture [1]. Focusing on the development, frontal bone ossifies in membrane from 2 primary centers which appear by the end of second month of fetal life and fuse first at the inner surface of 
skull by chondroid tissue[2].

Routine assessment of fetal faces in detection of malformations by using three- dimentional (3D) ultrasound has made it possible to assess reliably skull bones with their sutures. Ossification of frontal bones starts at $9 \mathrm{wks}$ in the middle of each supraorbital region and then spreads medially and laterally, so that by 11 wks the frontal bones appear as 'thick eyebrows'. Between 11 and 20 wks, ossification spreads upwards in a radial fashion. At $11 \mathrm{wks}$ frontal bones reach the midline at the nasal area and subsequently extend superiorly towards the future anterior fontanelle. Similarly the gap between the two frontal bones starts closing at around 16 wks in a supranasal region and with advancing gestation the two frontal bones enlarge and converge in the midline as if being zipped together. At 32 wks there is apparent closure of the metopic suture starting from the glabella and then moving upwards towards the anterior fontanelle[3].

Metopism can be related to various causes, such as abnormal growth of cranial bones, pathologic metopism triggered by hydrocephalus, growth interruption, heredity,atavism, stenocrotaphia ( abnormal narrowing of the temporal area of the head), plagiocephaly (cranial malformation causing a twisted and asymmetrical head because of synostosis of cranial sutures), mechanical causes and hormonal dysfunction. The genetic influence is currently the factor most accepted by the scientific community[4].

According to the classical anatomic literature, there are different incidences when ethnic groups are compared. The incidence of metopism in Alphine skulls is $63.2 \%$, while the smallest was reported in Australian and Scottish skulls [4]. Many factors are attributed or the persistence of metopic suture in adults which include abnormal growth of skull bones, hormones, cranial malformations, hydrocephalus, atavism, genetic causes. Knowledge regarding metopic suture is essential in studying the radiographs to avoid misinterpretation as fractures and also it is useful in evaluating medico-legal cases[2]. Marco Antonio [4] reported a study in South Brazilian population $34.97 \%$, Ajamani et al[5]. reported in Nigerian skulls 31.57\%.Janusz Skrzat et al [6]. evaluated the detailed morphology of 24 adult skulls with persistent metopic suture with application of fractal dimension.

It has been reported by various workers that the incidence of metopism is different in different races throughout the world. According to Brace (1915) metopism is present in 9.5\% of Scottish skulls, $8.5 \%$ Europian crania, 5.1\% in Mangolian subjects, $1.2 \%$ of Nigroes and $1 \%$ in Australian skulls. Breathnach (1958) reported it to be $7-10 \%$ in Europians, $4.5 \%$ in Yellow races[5].

Similar studies made in North Indian population Anjoo Yadav et al [1] reported metopism in $18.04 \%$, Neelima Pilli et al $^{2}$ reported in South Indian population 43.5\%, Dr Pankaj Wadekar et al'reported $23.75 \%$ in Maharashtra population.

\section{MATERIALS AND METHODS}

In the present study 100 skulls were observed in the museum of Anatomy department SIMS and RH Tumkur. Macerated skull and deformed skull were excluded from the study. The skulls with persistent metopic suture were thoroughly inspected and shape extent and length of the suture were noted the length was measured with the help of thread spread from nasion to bregma.

Fig. 1a: Metopic suture meeting, end-to-end, with the median Sagittal suture at Bregma (arrow). b) Metopic suture, not meeting end-to-end with the median Sagittal suture, at Bregma (arrows).

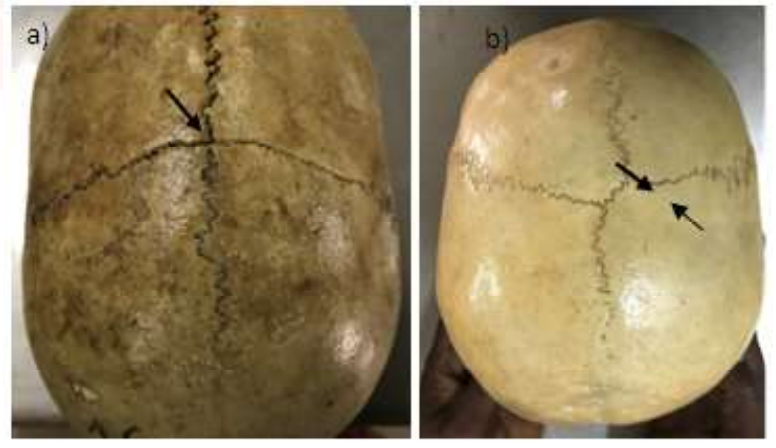

Fig. 2: Partial Metopic suture in the lower part of Frontal bone (just above Nasion) a) linear,b) U-shaped, c)V-shaped d) Y- shaped

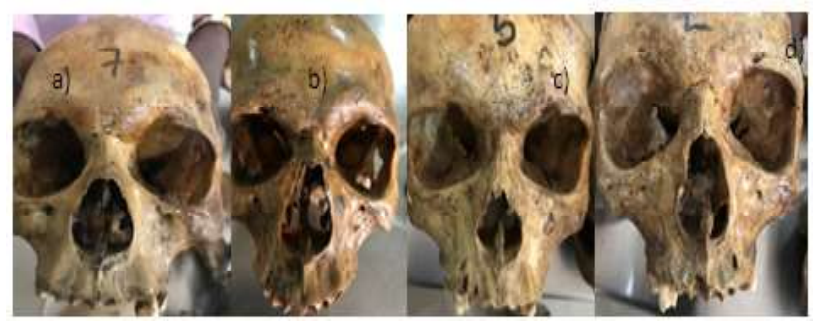

\section{RESULTS}

Among the 100 skulls studied metopic suture was present in 38 skulls, 3 were complete and 
35 were incomplete. One of the linear complete suture continue with sagittal suture measures $12.5 \mathrm{~cm}$, and the other 2 were ' $\mathrm{H}$ ' shaped measures $11.0 \mathrm{~cm}$ and $12.1 \mathrm{~cm}$. Remaining 35 skulls with incomplete suture, 26 were linear, 4 were ' $U$ ' shape, 4 were ' $V$ ' shape,1was ' $Y$ ' shape.

Table 1: Details of metopic suture.

\begin{tabular}{|c|c|c|c|c|}
\hline SI no & $\begin{array}{c}\text { Type of } \\
\text { suture }\end{array}$ & number & $\%$ & measurement \\
\hline \multirow{3}{*}{1} & Complete & 3 & \multirow{3}{*}{$2 \%$} & \\
\cline { 2 - 3 } & Linear & 1 & \multirow{2}{*}{$2 \%$} & $12.3 \mathrm{~cm}$ \\
\hline & 'H' shape & 2 & & $11.0 \mathrm{~cm}, 12.1 \mathrm{~cm}$ \\
\hline \multirow{3}{*}{2} & Incomplete & 35 & \multirow{3}{*}{$35 \%$} & \\
\cline { 2 - 3 } & Linear & 26 & \\
\cline { 2 - 3 } & 'U' shape & 4 & \\
\hline & 'V' shape & 4 & & \\
\cline { 2 - 3 } & 'Y' shape & 1 & & \\
\hline & Total & 37 & $38 \%$ & \\
\hline
\end{tabular}

Table 2: Measurements of incomplete linear sutures.

\begin{tabular}{|c|c|c|}
\hline SI no. & measurement & $\begin{array}{c}\text { No of skull } \\
\text { bones }\end{array}$ \\
\hline 1 & $0-1 \mathrm{~cm}$ & 15 \\
\hline 2 & $1.1-2 \mathrm{~cm}$ & 10 \\
\hline 3 & $2.1-3$ & 1 \\
\hline & Total & 26 \\
\hline
\end{tabular}

Table 3: Showing the incidence of metopic suture in various Indian studies.

\begin{tabular}{|c|c|c|c|c|}
\hline SI no & Authors & $\begin{array}{c}\text { \% complete M } \\
\text { S }\end{array}$ & $\begin{array}{c}\text { \% of incomplete } \\
\text { M S }\end{array}$ & Total \% \\
\hline 1 & K Kalyan et al [11] & 6.25 & 38.25 & 45 \\
\hline 2 & Pankaj et al [7] & 1.25 & 22.5 & 23.75 \\
\hline 3 & Neelima P et al [2] & 5 & 37.5 & 42.5 \\
\hline 4 & Hussain S et al [10] & 3.2 & 26.4 & 29.6 \\
\hline 5 & Anjoo Y et al [1] & 3.5 & 14.6 & 18.04 \\
\hline 6 & Dilip K et al [12] & 2 & 44 & 46 \\
\hline 7 & Present study & 3 & 35 & 38 \\
\hline
\end{tabular}

Table 4: Comparing the results with International studies.

\begin{tabular}{|c|c|c|c|c|}
\hline SI no & Authors & $\begin{array}{c}\text { \% Complete } \\
\text { M S }\end{array}$ & $\begin{array}{c}\text { \% Incomplete } \\
\text { M S }\end{array}$ & Total \% \\
\hline $\mathbf{1}$ & Marco A et al [4] & 7.04 & 32.39 & 39.43 \\
\hline $\mathbf{2}$ & Ajamani et al [5] & 3.4 & 31.57 & 34.97 \\
\hline $\mathbf{3}$ & Ivon do et al [8] & 4.48 & 5.22 & 9.7 \\
\hline $\mathbf{4}$ & Kimapora et al [9] & 2.83 & 4.67 & 7.5 \\
\hline $\mathbf{5}$ & Present study & 2 & 35 & 37 \\
\hline
\end{tabular}

\section{DISCUSSION}

According to different investigators, the most commonly observed shape of metopic suture is linear type and only in isolated cases have other forms of suture being found. These suture patterns have been described as radiating or having a wide side to side excursion[6].
Marco Antonio et al [4] reported a study of 71 skulls belonging to South Brazilian population. Complete M S was seen in 5 (7.04\%) skulls, and incomplete M S in 23 (32.39\%) skulls. Janusz et al[6] reported an analysis of 24 adult skulls with persistent M S in Jagiellon University, with detailed morphology and complexity denoted by fractal dimensions. Ajamani et al [5] reported a study of 206 Nigerian skulls, complete M S was seen in 7 (3.4\%) skulls, and incomplete M S in 65 (31.57\%) skulls. Ivon do et al [8] reported a study of 134 skulls in Macei AL, complete M S in 6 skulls (4.48\%) and incomplete in 7 skulls (5.22\%). Kimapora et al [9] reported a study of 706 skulls collected from grave yard in Thailand and found complete MS in 20 skulls (2.83\%) and incomplete M S in 33 skulls (4.67\%).

Anjoo Yadav et al [1] reported a study of 1020 skulls belonging to North Indian population, complete M S in 184 (18.04\%) skulls and incomplete M S in 148 (14.5\%) skulls. Pankaj Wadekar et al[7] reported a study of 80 skulls, complete $M$ $S$ in $1(1.25 \%)$ and incomplete M S in 18 (22.5\%).Hussain sahib et al[10] reported a study 125 skulls of south Indian population, complete M S seen in $4(3.2 \%)$ and incomplete M S in 33 ( $26.4 \%)$. Neelima $P$ et $\mathrm{al}^{2}$ reported a study of 180 skulls belonging to South Indian population complete M S was seen in $9(5 \%)$ and incomplete M S in 68 (37.77\%).K Kalyan et al[11] reported a study of 80 skulls of South Indian population, complete M S in 5 (6-25\%) skulls and incomplete M S in 31(38.75\%) skulls. Dilip Kumar et al [12] reported a study of 50 skulls complete M S in 1 and incomplete $M S$ in 22 skulls.

Average length of complete metopic suture in different studies, Marco A et al ${ }^{4} 12.92 \mathrm{~cm}$, Aksu et al [13] $12.3 \mathrm{~cm}$, Janusz et al [6] $12.31 \mathrm{~cm}$, Anjoo $Y$ et al[1] $12.8 \mathrm{~cm}$. In the present study it is $11.8 \mathrm{~cm}$, less when compared with other studies.

Commonest type of incomplete M S was linear in various studies, Marco A et al [4] 69.57\%, Aksu et al[13] 39.4\%, Ajamani et al [5] 24.27\%, Neelima et al [2] 8.8\%, K Kalyan et al [12] $18.75 \%$. In the present study 26 skulls showed linear incomplete M S in $26 \%$.

\section{CONCLUSION}

The persistence of metopic suture in adults which 
separates the frontal bones is of paramount importance in interpreting the radiological images and in evaluating medico legal cases. Persistent metopic suture can be diagnosed by $X$ ray of skull A-P view. To avoid wrong diagnosis in emergency conditions 2D and 3D CT scans are strongly recommended. Multiplanar reformat of CT scans also give valuable information about the shape, extent and closing status of metopic suture. Hence neurosurgeons should be aware of this anatomical variation while performing frontal craniotomy.

\section{Conflicts of Interests: None}

\section{REFERENCES}

[1]. Anjoo Yadav, Vinod Kumar, R.K. Srivastava. STUDY OF METOPIC SUTURE IN ADULT HUMAN SKULLS OF NORTH INDIA.J Anat. Soc India 2010; 59(2): 232236.

[2]. Neelima Pilli, Ragam Ravi Sunder.Persistant Metopic Suture in Various Forms in South Indian Adult Skulls - A study. International Journal of Scientific and Research Publications May 2013; Vol 3(5): ISSN 2250- 3153.

[3]. R.Chaoui, J.M. Levaillant, B. Benoit, C.Fero, P.Wegrzyn and K.H.Nicolaides. Three -dimensional sonographic description of abnormal metopic suture in second- and third- trimester fetuses. Ultrasound Obstet Gynecol 2005; 26:261-764.

[4]. Marco Antonio, Sant'Ana Castilho, Juliano Yasuo Oda, Debora de Mello Goncales Sant'Ana. Metopism in Adult Skulls from Southern Brazil. Int. J Morphol 2006; 24(1):61-66.

[5]. M. L. Ajamani, R.K. Mittal and S.P. Jain. Incidence of the Metopic Suture in Adult Nigerian Skulls. J. Anat 1983; 137,1: 177-183.
[6]. Janusz Skrzat,Jerzy Walocha, Jaroslaw Zawilinski.A note on the morphology of metopic suture in the human skull. Folia Morphol vol 63, No 4: 481-484.

[7]. Pankaj R Wadekar,Dr Sunil J.Pundge, Dr M.P. Fulpatil, Dr S.V.Pandit. Study of Incidence of metopic suture in adult skulls. Indian Journal of Basic and Applied Medical Research, Dec 2014; Vol 4(1): 277-283

[8]. Ivan do Nascimento do Silva, Katharina Juca de Moraes Fernades, Antonio Jose Casado Ramalho, Rodrigo Freitas Monte Bispo, Celio Fernando de Sousa Rodrigues and Jose Aderval Aragao. Occurrence of Metopism in Dry Crania of Adult Brazilians. ISRN Anat.2013; 2013;158341.

[9]. Kimapora Khamanarong, Panya Thamsuk,Worawut Woraputtapora, Malivalaya Namking, Tarinee Sawatpanich, Yanyong Toomsan and Sitthichai lamsaard. Incidence of Metopism in Adult Thai Skulls. Int J of Morphol 2015; 33(1): 51-54.

[10]. Hussan Saheb S, Mavishetter G.F, Thomas S.T, Prasanna L.C. Incidence of metopic suture in adult South Indian Skulls. J. Biomed Sci and Res. 2010; Vol 2(4):223-226.

[11]. K Kalyan Chakravarthi, Nelluri Venumadhav. 'Morphological Study of Metopic Suture in adult South Indian Skulls'. I J of Medical \& Health Sciences April 2012; Vol 1, Issue 2: page 23-28.

[12]. Dr T H Dilip Kumar, Dr S S Rajasekar.Metopic Suture and it's variations. Indian J of Basic and Applied Medical Research Sept 2014; Vol 3, issue 4: 42-45.

[13]. Aksu F,Cirpan S, Mas NG, Karabekir S, Magden AO. Anatomic features of metopic suture in adult dry skulls.The J of Craniofacial Surgery 2014; 25(3): 1044-1046.

How to cite this article:

Sharada B Menasinkai, Vidya H K, M N Koti. STUDY OF METOPIC

SUTURE. Int J Anat Res 2019;7(2.1):6341-6344. DOI: 10.16965/ ijar.2019.111 